\title{
Diagnostic value of T-Spot TB combined with INF- $\gamma$ and IL-27 in tuberculous pleurisy
}

\author{
MENG ZHANG ${ }^{1}$, DEDONG XIONG ${ }^{1}, \mathrm{HONGXIA} \mathrm{LI}^{2}, \mathrm{ZONGLAN} \mathrm{WANG}^{3}$ and RENZHE LI ${ }^{4}$ \\ Departments of ${ }^{1}$ Clinical Laboratory, ${ }^{2}$ Obstetrics and ${ }^{3}$ Hemodialysis Room, \\ Binzhou City Center Hospital, Binzhou, Shandong 251700; ${ }^{4}$ Department of Medical Laboratory, \\ Jining First People's Hospital, Jining, Shandong 272111, P.R. China
}

Received July 13, 2017; Accepted November 1, 2017

DOI: $10.3892 /$ etm.2017.5464

\begin{abstract}
The purpose of the present study was to investigate the diagnostic value of T cells spot test (T-Spot TB) combined with interferon- $\gamma$ (INF- $\gamma$ ) and interleukin-27 (IL-27) in tuberculous pleurisy. Sixty patients with tuberculous pleurisy (observation group) and 60 patients with non-tuberculous pleurisy (control group) were enrolled in this study. T-Spot TB was performed to detect the pleural effusion of two groups of patients. Levels of IFN- $\gamma$ and IL-27 in serum and pleural effusion were detected by enzyme-linked immunosorbent assay (ELISA). Relative expression of IFN- $\gamma$ mRNA and IL-27 mRNA in peripheral blood mononuclear cells were detected by RT-PCR. Positive rate of T-Spot TB in observation group was $96.7 \%$ (58 cases), which was significantly higher than that in control group $(\mathrm{p}<0.05)$. Concentration of INF- $\gamma$ in pleural effusion of observation group was $468.6 \pm 24.8 \mathrm{ng} / \mathrm{l}$, which was significantly higher than that in control group $(131.3 \pm 18.7 \mathrm{ng} / \mathrm{l}, \mathrm{p}<0.05)$. Concentration of IL-27 in pleural effusion of observation group was $423.4 \pm 37.2 \mathrm{ng} / \mathrm{l}$, which was significantly higher than that in control group $(116.2 \pm 15.5 \mathrm{ng} / 1, \mathrm{p}<0.05)$. Concentrations of INF- $\gamma$ and IL-27 in serum of observation group were $48.2 \pm 13.4$ and $41.7 \pm 10.6 \mathrm{ng} / \mathrm{l}$, respectively, which were significantly higher than those in control group (38.6 \pm 11.2 and 35.3 $\pm 8.4 \mathrm{ng} / \mathrm{l}, \mathrm{p}<0.05)$. Relative expression levels of INF- $\gamma$ mRNA and IL-27 mRNA in observation group were significantly higher than those in control group $(\mathrm{p}<0.05)$. Therefore, combination of T-Spot TB with INF- $\gamma$ and IL-27 has significant application value in the clinical diagnosis of tuberculous pleurisy, and should be popularized.
\end{abstract}

\section{Introduction}

Tuberculous pleurisy is a respiratory disease caused by mycobacterium tuberculosis with fever, chest pain and cough as the

Correspondence to: Dr Renzhe Li, Department of Medical Laboratory, Jining First People's Hospital, 99 Shixian Road, High Tech Zone, Jining, Shandong 272111, P.R. China

E-mail: renzhe_li@163.com

Key words: tuberculous pleurisy, T-Spot TB, interferon- $\gamma$, interleukin-27 main clinical manifestations (1). The diagnosis of tuberculous pleurisy is still challenged by the restrictions on detection methods and techniques. The application of chest radiograph and ultrasound techniques in the diagnosis of tuberculous pleurisy were limited by the poor specificity, which in turns increase the difficulties of the diagnosis and treatment of this disease $(2,3)$. Cellular immune function plays an important role in the development of immune diseases. Related studies showed that mycobacterium tuberculosis control was closely related with macrophage $(4,5)$. T cells spot test (T-Spot TB) was reported to possess relatively high sensitivity in the detection of extrapulmonary tuberculosis (6). Interferon- $\gamma($ IFN- $\gamma$ ) and interleukin-27 (IL-27) which can participate in a variety of inflammatory reactions, can induce tissue damage and inflammatory response. This study aimed to investigate the application value of T-Spot TB combined with INF- $\gamma$ and IL-27 in clinical diagnosis of patients with tuberculous pleurisy with the expectation of providing new insights for the clinical diagnosis and treatment of this disease.

\section{Materials and methods}

General information. A total of 60 patients with tuberculous pleurisy (tuberculous pleural effusion) were selected in Binzhou City Center Hospital from March 2017 to September 2017 and the patients included 33 males and 27 females and the ages ranged from 32 to 73 years with an average age of $45.6 \pm 2.5$ years. At the same time, 60 patients with non-tuberculous pleurisy (malignant pleural effusion) were selected as control group and those patients included 34 males and 26 females and the ages ranged from 33 to 72 years with an average age of $45.8 \pm 2.7$ years. Patients in control group included 27 cases of pleural metastasis from lung cancer, 16 cases of pleural metastasis from breast cancer, 8 cases of lymphoma, 6 cases of pleural metastasis from gastric cancer and 3 cases of other types. Pleural effusion was detected in both groups of patients by physical examination or imaging. None of those patients received intervention treatment. This study was approved by the Ethics Committee of Binzhou City Center Hospital. All patients signed informed consent. Pregnant women and patients with HIV infection were excluded.

Methods. Pleural effusion $(30 \mathrm{ml})$ was collected from each patient with $24 \mathrm{~h}$ after admission through thoracentesis. Pleural 
effusion was centrifuged at 2,500 $\mathrm{x} \mathrm{g} / \mathrm{min}$ and was separated into 3 layers. Lymphocyte layer in the middle was collected for T-Spot TB test. The upper layer was used to detect the levels of IFN- $\gamma$ and IL-27. T-Spot TB test was performed by ELISPOT count. Levels of IFN- $\gamma$ and IL-27 were detected by ELISA (Sigma-Aldrich, St. Louis, MO, USA).

Peripheral blood was extracted from each patient with $24 \mathrm{~h}$ after admission. After centrifugation at $1,500 \mathrm{x} \mathrm{g} / \mathrm{min}$ for $10 \mathrm{~min}$, the precipitation contained a large number of mononuclear cells was collected for total RNA extraction using RNA extraction kit (TransGen Biotech, Beijing, China) according to the manufacturer's instructions. Total RNA was subjected to agarose gel electrophoresis to check the integrity of RNA and the absorbance was determined by UV spectrophotometer to determine RNA content. Reverse transcription was performed using a reverse transcription kit (Invitrogen Life Technologies, Carlsbad, CA, USA). Relative expression levels of IFN- $\gamma$ mRNA and IL-27 mRNA in peripheral blood mononuclear cells were detected by real-time PCR. PCR primers were designed using primer 3.0. Primer sequences are listed in Table I. PCR reaction conditions were as follows: $95^{\circ} \mathrm{C}$ for $3 \mathrm{~min}$, followed by 40 cycles of $95^{\circ} \mathrm{C}$ for $10 \mathrm{sec}, 50^{\circ} \mathrm{C}$ for $30 \mathrm{sec}$ and $72^{\circ} \mathrm{C}$ for $15 \mathrm{sec}$. PCR products were subjected to agarose gel electrophoresis and the results were photographed. Optical density of each band was scanned by an optical density scanner. With $\beta$-actin as endogenous control, relative expression levels of IFN- $\gamma$ and IL-27 were determined.

ROC curve analysis was performed using graphpad software. The accuracies of T-Spot TB alone and the combined method in the diagnosis of tuberculous pleurisy were compared.

Determination of the results of T-Spot TB. Results of T-Spot TB were determined according to the instructions of the kit (7): i) Positive: Spot-forming cells (SFC) of negative control $<6$ and SFC of detection well-SFC of negative control $>6$; ii) positive: $\mathrm{SFC}$ of negative control $\geq 6$ and $\mathrm{SFC}$ of detection well was twice as many as that of negative control.

Statistical analysis. SPSS 21.0 software (Cyber Camera, Sichuan, China) was used for statistical analysis. Comparisons of measurement data between groups were performed by t-test. Results of T-spot TB test were subjected to chi-square test. $\mathrm{P}<0.05$ was considered to indicate a statistically significant difference.

\section{Results}

Comparison of results of T-Spot TB test between two groups. The positive rate of T-Spot TB in the observation group was $96.7 \%$ (58 cases), which was significantly higher than that in the control group $(\mathrm{p}<0.05)$ (Table II).

Comparison of INF- $\gamma$ and IL-27 levels in pleural effusion between two groups. INF- $\gamma$ content in pleural effusion of observation group was $468.6 \pm 24.8 \mathrm{ng} / \mathrm{l}$, which was significantly higher than that in control group $(131.3 \pm 18.7 \mathrm{ng} / \mathrm{l}$, $\mathrm{p}<0.05)$. IL-27 content in pleural effusion of observation group was $423.4 \pm 37.2 \mathrm{ng} / \mathrm{l}$, which was significantly higher than that in control group $(116.2 \pm 15.5 \mathrm{ng} / \mathrm{l}, \mathrm{p}<0.05)$ (Table III).
Table I. Primer sequences.

\begin{tabular}{ll}
\hline Genes & \multicolumn{1}{c}{ Sequences } \\
\hline IFN- $\gamma$ & F: 5'-ACTTCTTTGGCTTAATTCTC-3' \\
& R: 5'-ATTGCTTTGCGTTGGA-3' \\
IL-27 & F: 5'-AGCCTTCGCATCATCAGC-3' \\
& R: 5'-TTATTGGGCACCCAGCAT-3' \\
$\beta$-actin & F: 5'-TCAGGTCATCACTATCGGCAAT-3' \\
& R: 5'-AAAGAAAGGGTGTAAAACGCA-3' \\
\hline
\end{tabular}

INF- $\gamma$, interferon- $\gamma$; IL-27, interleukin-27; F, forward; R, reverse.

Table II. Comparison of results of T-Spot TB test between two groups.

\begin{tabular}{lcccccc}
\hline Groups & No. positive & $\begin{array}{c}\text { Spot } \\
\text { negative }\end{array}$ & $\begin{array}{c}\text { Positive } \\
\text { rate }(\%)\end{array}$ & $\chi^{2}$ & P-value \\
\hline $\begin{array}{l}\text { Observation } \\
\text { group }\end{array}$ & 60 & 58 & 2 & 96.7 & 12.503 & $<0.05$ \\
$\begin{array}{l}\text { Control } \\
\text { group }\end{array}$ & 60 & 1 & 59 & 1.7 & & \\
\hline
\end{tabular}

T-Spot TB, T cells spot test.

Table III. Comparison of INF- $\gamma$ and IL-27 levels in pleural effusion between two groups.

\begin{tabular}{lccc}
\hline Groups & No. & $\begin{array}{c}\text { INF- } \gamma \\
(\mathrm{ng} / \mathrm{l})\end{array}$ & $\begin{array}{c}\text { IL-27 } \\
(\mathrm{ng} / \mathrm{l})\end{array}$ \\
\hline $\begin{array}{l}\text { Observation } \\
\text { group }\end{array}$ & 60 & $468.6 \pm 24.8$ & $423.4 \pm 37.2$ \\
$\begin{array}{l}\text { Control } \\
\text { group }\end{array}$ & 60 & $131.3 \pm 18.7$ & $116.2 \pm 15.5$ \\
t-test & & 7.903 & 8.521 \\
P-value & & $<0.05$ & $<0.05$ \\
\hline
\end{tabular}

INF- $\gamma$, interferon- $\gamma$; IL-27, interleukin-27.

Comparison of INF- $\gamma$ and IL-27 levels in serum effusion between two groups. Level of INF- $\gamma$ in pleural effusion of observation group was $48.2 \pm 13.4 \mathrm{ng} / \mathrm{l}$, which was significantly higher than that in the control group $(38.6 \pm 11.2 \mathrm{ng} / \mathrm{l}, \mathrm{p}<0.05)$. Level of IL-27 in pleural effusion of the observation group was $41.7 \pm 10.6 \mathrm{ng} / \mathrm{l}$, which was significantly higher than that in the control group $(35.3 \pm 8.4 \mathrm{ng} / \mathrm{l}, \mathrm{p}<0.05)$ (Table IV).

Comparison of the relative expression level of INF- $\gamma$ mRNA in peripheralbloodmononuclear cells between two groups. Relative expression level of INF- $\gamma$ mRNA in observation group was significantly higher than that in control group $(\mathrm{p}<0.05)$ (Fig. 1).

Comparison of the relative expression level of IL-27 mRNA in peripheral blood mononuclear cells between two groups. 
Table IV. Comparison of INF- $\gamma$ and IL-27 levels in serum effusion between two groups.

\begin{tabular}{lccc}
\hline Groups & No. & $\begin{array}{c}\text { INF- } \gamma \\
(\mathrm{ng} / \mathrm{l})\end{array}$ & $\begin{array}{c}\text { IL-27 } \\
(\mathrm{ng} / \mathrm{l})\end{array}$ \\
\hline $\begin{array}{l}\text { Observation } \\
\text { group }\end{array}$ & 60 & $48.2 \pm 13.4$ & $41.7 \pm 10.6$ \\
$\begin{array}{l}\text { Control } \\
\text { group }\end{array}$ & 60 & $38.6 \pm 11.2$ & $35.3 \pm 8.4$ \\
$\begin{array}{l}\text { t-test } \\
\text { P-value }\end{array}$ & & 7.742 & 8.366 \\
\hline
\end{tabular}

INF- $\gamma$, interferon- $\gamma$; IL-27, interleukin-27.

A

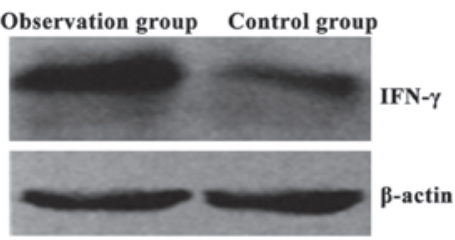

B

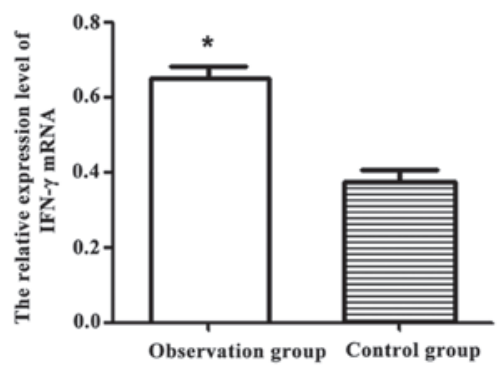

Figure 1. Comparison of relative expression levels of INF- $\gamma$ between groups. (A) Representative result of western blot analysis, expression level of INF- $\gamma$ protein in observation group was significantly higher than that of control group. (B) qRT-PCR results, the relative expression level of INF- $\gamma$ mRNA in observation group was significantly higher than that of control group. ${ }^{*}$ Compared with control group, $\mathrm{p}<0.05$. INF- $\gamma$, interferon- $\gamma$.

Relative expression level of IL-27 mRNA in observation group was significantly higher than that in control group ( $\mathrm{p}<0.05)$ (Fig. 2).

Comparison of ROC curves of T-Spot TB alone and the combined method. ROC curve showed that the accuracy of the combined method was significantly higher than that of T-Spot TB alone (Fig. 3).

\section{Discussion}

As a common unilateral pleural effusion disease, tuberculous pleurisy can affect patients at any age. The formation of pleural effusion is the main feature of tuberculous pleurisy $(8,9)$. Studies have shown that the incidence of tuberculous pleurisy was relatively higher world widely and the main type was tuberculous pleurisy (10-12). Both the observation of clinical symptoms and the detection of pleural effusion
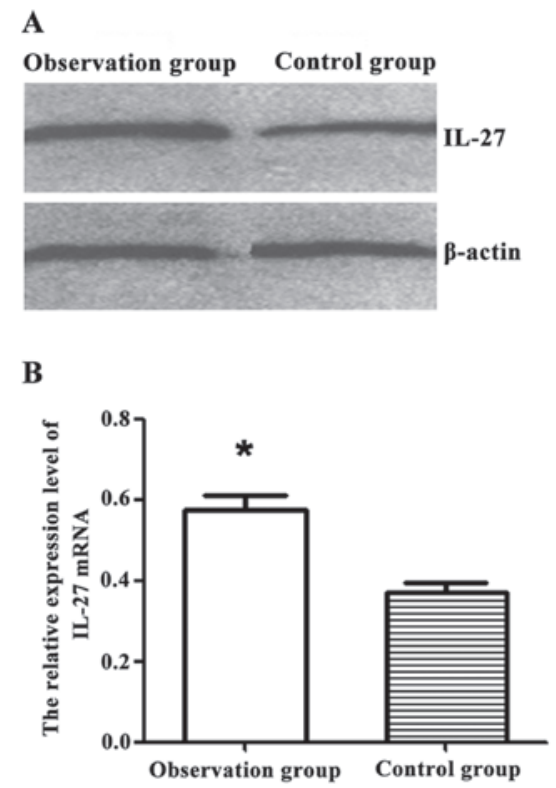

Figure 2. Comparison of relative expression levels of IL-27 between groups. (A) Representative result of western blot analysis using software showed that the expression level of IL-27 protein in observation group was significantly higher than that of control group. (B) qRT-PCR results, the relative expression level of IL-27 mRNA in observation group was significantly higher than that of control group. *Compared with control group, p $<0.05$. IL-27, interleukin-27.

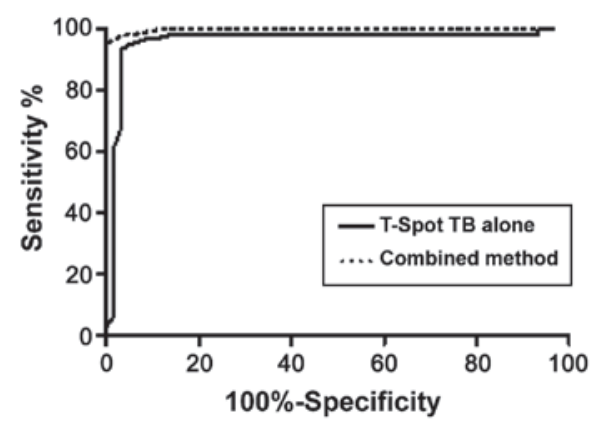

Figure 3. Comparison of accuracies of T-Spot TB alone and the combined method in the diagnosis of tuberculous pleurisy. The accuracy of the combined method was significantly higher than that of T-Spot TB alone. T-Spot TB, T cell spot test.

by biochemical examination are important for the diagnosis of tuberculous pleurisy. It is worth noting that the lack of typical manifestations and the low specificities of biochemical indicators and routine examination increase the difficulties in the diagnosis (13-15). Therefore, the development of reliable diagnostic methods for tuberculous pleurisy is needed.

At the main method used in the diagnosis of tuberculosis, T-Spot TB can be used to accurately determine the number of cells that can secrete antibodies and cytokines. Therefore, the results of T-Spot TB can reflect the level of cytokines in vivo $(16,17)$. Studies have shown that the use of T-Spot TB technology can improve the positive rate of the diagnosis of tuberculous pleurisy, but misdiagnosis have been reported $(18,19)$. Therefore, the application of joint diagnosis is needed to increase the positive rate of diagnosis of tuberculous pleurisy. 
IFN- $\gamma$ is a characteristic cytokine of T helper lymphocyte subsets (Th1). After mycobacterium tuberculosis infection, macrophages in lesion site will be activated and IFN- $\gamma$ content in pleural effusion and blood will gradually increase (20). Studies have shown that IL-27 has a dual regulatory effect on Th1-type immune responses in tuberculous diseases $(21,22)$. On one hand, IL-27 can induce the differentiation of $\mathrm{CD}^{+}$in to Th1. On the other hand, IL-27 can inhibit Th1 cell proliferation, thus inhibiting the damage to the body caused by Th1 type of immune response.

Results of this study showed that the positive rate of T-Spot TB in observation group was $96.7 \%$ (58 cases), which was significantly higher than that in control group $1.7 \%$ ( 1 case), indicating that the positive rate of T-Spot TB detection is relatively high and this method can be used to rapidly detect mycobacterium tuberculosis infection. At the same time, levels of INF- $\gamma$ and IL-27 in pleural effusion of observation group were significantly higher than those in control group $(p<0.05)$. The results suggest that levels of INF- $\gamma$ and IL-27 in pleural effusion of patients with tuberculous pleurisy were significantly higher than those in patients with malignant pleural effusion, indicating the high specificity. We also found that the levels of INF- $\gamma$ and IL-27 in serum of observation group were significantly higher than those in control group. Relative expression levels of INF- $\gamma$ mRNA and IL-27 mRNA in observation group were significantly higher than those in control group $(\mathrm{p}<0.05)$. Those results suggest that INF- $\gamma$ and IL-27 may participate in the development of tuberculous pleurisy. Therefore, T-Spot TB test combined with the detection of INF- $\gamma$ and IL-27 levels can be used to detect tuberculous pleurisy at the early stage, which in turn benefit the early treatment and prevent delayed treatment.

\section{References}

1. Ye ZJ, Xu LL, Zhou Q, Cui A, Wang XJ, Zhai K, Wang Z, Tong ZH and Shi HZ: Recruitment of IL-27-producing CD4 ${ }^{+}$ T cells and effect of IL-27 on pleural mesothelial cells in tuberculous pleurisy. Lung 193: 539-548, 2015.

2. Cao GQ, Li L, Wang YB, Shi ZZ, Fan DY and Chen HY: Treatment of free-flowing tuberculous pleurisy with intrapleural urokinase. Int J Tuberc Lung Dis 19: 1395-1400, 2015.

3. Li M, Luo Z, Zhu W, Khan RS, Saeed U and Shi S: Diagnostic accuracy of tumor necrosis factor-alpha assay for tuberculous pleurisy: A PRISMA-compliant meta-analysis. Medicine (Baltimore) 95: e5510, 2016.

4. Koh WJ: Progression of tuberculous pleurisy: From a lymphocytepredominant free-flowing effusion to a neutrophil-predominant loculated effusion. Tuberc Respir Dis (Seoul) 80: 90-92, 2017.

5. Kim MC, Kim SM, Lee SO, Choi SH, Kim YS, Woo JH and Kim SH: A diagnostic algorithm for tuberculous pleurisy using the ELISPOT assay on peripheral blood and pleural effusion. Infect Dis (Lond) 48: 688-694, 2016.

6. Sheikh G, Neela VSK, Pydi SS, Suryadevara NC, Gaddam R, Gaddam SL, Auzumeedi SK and Valluri VL: Genetic association of interferon gamma induced protein-10 (IP-10), 10 gene polymorphisms with TB pleurisy susceptibility in south Indian population. Open J Immunol 5: 72-78, 2015.
7. Yoshino Y, Wakabayashi Y, Seo K, Koga I, Kitazawa T and Ota Y: Hyaluronic acid concentration in pleural fluid: Diagnostic aid for tuberculous pleurisy. J Clin Med Res 7: 41-44, 2015.

8. Tural Önür S, Sökücü SN, Dalar L, Seyhan EC, Akbaş A and Altin S: Are soluble IL-2 receptor and IL-12p40 levels useful markers for diagnosis of tuberculous pleurisy? Infect Dis (Lond) 47: 150-155, 2015.

9. Lee BH, Yoon SH, Yeo HJ, Kim DW, Lee SE, Cho WH, Lee SJ Kim YS and Jeon D: Impact of implementation of an automated liquid culture system on diagnosis of tuberculous pleurisy. J Korean Med Sci 30: 871-875, 2015.

10. Li D, Shen Y, Fu X, Li M, Wang T and Wen F: Combined detections of interleukin-33 and adenosine deaminase for diagnosis of tuberculous pleural effusion. Int J Clin Exp Pathol 8: 888-893, 2015

11. Omura S, Nakaya M, Mori A, Oka M, Ito A, Kida W, Inayoshi Y, Inoue A, Fuchigami T and Takamori M: A clinical review of 38 cases of cervical tuberculous lymphadenitis in Japan - The role of neck dissection. Auris Nasus Larynx 43: 672-676, 2016.

12. Tada A, Kawai H, Matsumoto H, Kimura G, Okada C, Soda R and Takahashi K: Tumor markers in pleural effusion of patients with lung cancer and patients with tuberculous pleurisy. Nihon Kokyuki Gakkai Zasshi 40: 106-12, 2002.

13. Aggarwal AN, Agarwal R, Gupta D, Dhooria S and Behera D: Interferon gamma release assays for diagnosis of pleural tuberculosis: A systematic review and meta-analysis. J Clin Microbiol 53: 2451-2459, 2015.

14. Chen ML, Yu WC, Lam CW, Au KM, Kong FY and Chan AY: Diagnostic value of pleural fluid adenosine deaminase activity in tuberculous pleurisy. Clin Chim Acta 341: 101-107, 2004.

15. Wu X, Ma Y, Li D, Yang Y, Liang Y, Xue H and Zhang J: Diagnostic value of ELISPOT technique for osteoarticular tuberculosis. Clin Lab 60: 1865-1870, 2014

16. Gao Y, Ou Q, Huang F, Wang S, Shen L, Shen Y, Wu J, Zheng J, Weng X,Zhang W, et al: Improved diagnostic power by combined interferon-gamma release assay and nested-PCR in tuberculous pleurisy in high tuberculosis prevalence area. FEMS Immunol Med Microbiol 66: 393-398, 2012

17. Kobashi Y, Mouri K, Obase Y, Kato S and Oka M: Clinical application of T-SPOT.TB using pleural effusion as a diagnostic method for tuberculosis infection. Open J Respir Dis 4: 64-72, 2014.

18. Wang JL, Zhao GW, Zhang ZQ, Wang XF and Wang MS: Clinicopathologic characteristics of pediatric tuberculous pleural effusion: A retrospective analysis of 112 consecutive cases. Eur Rev Med Pharmacol Sci 19: 2978-2982, 2015.

19. Losi M, Bossink A, Codecasa L, Jafari C, Ernst M, Thijsen S, Cirillo D, Ferrarese M, Greinert U, Fabbri LM, et al; European Tuberculosis Network TBNET: Use of a T-cell interferon-gamma release assay for the diagnosis of tuberculous pleurisy. Eur Respir J 30: 1173-1179, 2007.

20. Keng LT, Shu CC, Chen JY, Liang SK, Lin CK, Chang LY, Chang CH, Wang JY, Yu CJ and Lee LN: Evaluating pleural ADA, ADA2, IFN- $\gamma$ and IGRA for diagnosing tuberculous pleurisy. J Infect 67: 294-302, 2013.

21. Liu BY, Bu XM and Wang GQ: Trace elements analysis of urine and hair in tuberculous pleurisy. Biol Trace Elem Res 143: 1319-1324, 2011.

22. Kim MC, Kim SM, Lee SO, Choi SH, Kim YS, Woo JH and Kim SH: A diagnostic algorithm for tuberculous pleurisy using the ELISPOT assay on peripheral blood and pleural effusion. Infect Dis (Lond) 48: 688-694, 2016.

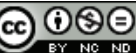

This work is licensed under a Creative Commons Attribution-NonCommercial-NoDerivatives 4.0 International (CC BY-NC-ND 4.0) License. 